\title{
INDIVIDUAL MOVEMENT OF LARGE CARABIDS AS A LINK FOR ACTIVITY DENSITY PATTERNS IN VARIOUS FORESTRY TREATMENTS
}

\author{
Jana RŮŽičKová ${ }^{1}$, SÁndor Bérces ${ }^{2}$, Szlávko Ackov ${ }^{3}$ and Zoltán Elek ${ }^{1}$ \\ ${ }^{1}$ MTA-ELTE-MTM Ecology Research Group, Biological Institute, Eötvös Loránd University \\ Pázmány Péter sétány 1/C, 1117 Budapest, Hungary \\ E-mails: jr.tracey@seznam.cz,http://orcid.org/0000-0001-9703-4538 \\ zoltan.elek2@gmail.com,https://orcid.org/0000-0001-6026-6300 \\ ${ }^{2}$ Duna-Ipoly National Park Directorate, Költố utca 21, 1121 Budapest, Hungary \\ E-mail: bercess@gmail.com, https://orcid.org/0000-0003-2920-8756 \\ ${ }^{3}$ Budapest Forestry Company, Hévízi út 4/a, 1033 Budapest, Hungary \\ E-mail: szlavko@yahoo.co.uk
}

Activity density is one of the most common measures in ground-dwelling arthropods, including carabids. It is based on individuals' activity and population density, yet there is no available evidence whether the individual movement can be a good proxy for activity density. Therefore, in our study, we aimed to explore this link in two large ground beetle species, Carabus scheidleri Panzer, 1799 and C. coriaceus Linnaeus, 1758, in an oak-hornbeam forest in Hungary. We used pitfall traps for activity density and capture-mark-recapture and radio telemetry to record individual movement patterns in different forestry treatments, preparation cuttings and clear-cuttings, and their control plots. We found a link between activity density and movement of individuals via treatment types. Although activity density, mean walking speed and the proportion of active time were significantly higher in both treatments than in control plots, the individual movement revealed only temporal use of these habitats. Beetles left treatments within a few days. We concluded that the high turnover of individuals in treatments might indirectly suggest that these habitats probably act as temporary foraging sites for both species.

Keywords: Carabus spp., forest management, capture-mark-recapture, pitfall traps, radio telemetry.

\section{INTRODUCTION}

Ecological studies on assemblages of ground-dwelling arthropods often involve the use of pitfall traps (GreENSLAde 1964, Lövei \& SUNDERLAND 1996). It is one of the oldest, most efficient, and convenient, but also heavily criticized sampling techniques because the numbers caught do not reflect the absolute abundance of a particular species (Topping \& Sunderland 1992, Woodcock 2005, Kотze et al. 2011). The capture rate is proportional to the interaction between individuals' movement activity and population density in the sampled habitat (Lövei \& Sunderland 1996, Brown \& Matthews 2016). Therefore, the pitfall trap catches should be rather treated as 'activity density' than abundance (Thomas et al. 1998, LANG 2000). Moreover, the trapping efficiency is not 
the same for all species due to species-specific behavioural responses (HALSALL \& WRATTEN 1988) which may lead to underestimation of relatively sessile but very abundant species in the trap catches compared to rare but more active species (Topping \& Sunderland 1992, Lang 2000, Woodcock 2005). Regardless of these limitations, activity density is still one of the most common measures for ground-dwelling arthropods in community ecology studies. Carabids (Coleoptera: Carabidae) are one of the most frequently caught groups in the pitfall traps; thus, they are among the best indicators taxa within arthropods with an excellent background about their ecology and behaviour, especially for movement characteristics (Thiele 1977, Lövei \& Sunderland 1996).

Carabids' movement is modified by several factors, including biotic and abiotic ones. For instance, sex (Thomas et al. 1998, Kagawa \& Maeto 2009), breeding season (KÁDÁr et al. 2017), and hunger level (Wallin \& Еквом 1994, Szyszko et al. 2004) are considered as the most influential biotic factors affecting carabids. From environmental variables, especially (micro)habitat (BAARs 1979, RiecKen \& RATHS 1996, BÉRCes \& RŮžIČKovÁ 2019), temperature (HoNĚK 1997, SASKa et al. 2013, RŮžičKová \& VeSELÝ 2016) and light intensity (HALSALL \& Wratten 1988, SzYszko et al. 2005) have been reported to influence carabid activity and distribution significantly. Moreover, these factors are confounded by behavioural peculiarities of each species at both the inter- and intra-individual level (BAILEY et al. 2020). Although the research interest in the individual movement of carabids is growing, especially with the technical development in radio-tracking and remote sensing, the selection of species is still biased and mostly focused on large or very common carabids. Without information on the species-specific movement activity, it is almost impossible to correlate the catches from pitfall traps to the factual abundance/population density estimations (Topping \& Sunderland 1992, Woodcock 2005, Brown \& Matthews 2016). This concept is crucial for reliable interpretation of pitfall trap data; nevertheless, the link between movement parameters and activity density is still poorly understood. Decades ago, only GRÜM $(1971 a, b)$ reported that beetles walked faster in unsuitable habitats resulting in higher trap catches than expected, suggesting that higher activity density likely does not automatically mean a particular species or an assemblage prefers that sampled habitat.

In this study, we aimed to explore in detail whether the individual movement can be a good proxy for activity density of carabids in an oak-hornbeam Hungarian forest managed by different forestry treatments. A previous study (Elek et al. 2018) showed significant effects of forest management on species composition of carabids. These findings were based on trap catches and report only assemblage-level responses. However, individuals' movement plasticity may bias species-specific responses to silvicultural treatments that can not be revealed by pitfall trapping. Therefore, we selected two common large flightless carabid species in the experimental area: Carabus (Morphocarabus) 
scheidleri Panzer, 1799 and C. (Procrustes) coriaceus Linnaeus, 1758. First (1), we estimated the potential habitat utilization by capture-mark-recapture and radio telemetry between two forestry treatments (preparation cuttings and clear-cutting) and their controls. Then (2), we sought to link activity density data and movement patterns of individuals revealing true habitat utilization. We focused especially on individual movements within and between habitats, trajectory profiles, mean speed and the proportion of the active time.

\section{MATERIAL AND METHODS}

Study site - Our study was implemented as a part of the Pilis Forestry System Experiment (https://www.piliskiserlet.okologia.mta.hu/en), located in the vicinity of Pilisszántó village in the Pilis Mountains, northern Hungary $\left(47.6741^{\circ} \mathrm{N}, 18.9105^{\circ} \mathrm{E}\right)$. The experimental area (40 ha) was a structurally homogenous, 80 years old, managed two-layered sessile oakhornbeam forest. The upper canopy layer was dominated by Quercus petraea (Matt.) Liebl., 1784, Q. cerris Linnaeus, 1753, Fagus sylvatica Linnaeus, 1753 and Prunus avium Linnaeus, 1755, while Carpinus betulus Linnaeus, 1753 and Fraxinus ornus Linnaeus, 1753 made the lower layer. In 2014, four different forestry treatments in two different silvicultural systems were established to test the effect of these treatments on forest biodiversity and regeneration (see ElEK et al. 2018 for further details). For this study, we used two of the four implemented treatments representing characteristic stages of the rotation forestry system: (1) Clear-cutting (CC) was a circular clear-cutting area of $80 \mathrm{~m}$ diameter surrounded by the closed-canopy stand. (2) Preparation cutting (P) was created when $30 \%$ of the total basal area of the dominant tree layer and the whole secondary tree layer were removed in a spatially uniform way in a circle of $80 \mathrm{~m}$ diameter. Treatments were replicated in six blocks that also included control unmanaged forest stands (C), leading into 18 sampling plots in total.

Target species - We selected two large ground beetles, Carabus scheidleri and C. coriaceus. The first species, variable in colour morphs and $27-30 \mathrm{~mm}$ long C. scheidleri, was used for capture-mark-recapture. It is a generalist predator, predominantly occurring in forests, but it is also known from arable fields, meadows, and vineyards (TuRIN et al. 2003). The species overwinters both as larvae and as adults with overlapping generations and several reproductive periods (ANDorkó \& KÁdÁr 2009). The second species, C. coriaceus, is one of the most common species in the area. It is associated with various types of temperate forests, orchards and vineyards (Turin et al. 2003). With a size of 33-40 mm, it is the largest carabid species in Hungary and suitable to mount radio transmitters (ELEK et al. 2019). It is a typical autumn breeder with an activity peak in autumn when copulation and oviposition occur and a second smaller peak in spring (TuRIN et al. 2003).

Activity density - pitfall trapping - The activity density of C. scheidleri and C. coriaceus was recorded by pitfall traps made of $85 \mathrm{~mm}$ diameter plastic cups and filled with $50 \%$ solution of propylene glycol and water. A dark green roof was installed above every trap. We installed four pitfall traps in CC and P treatments as well as in control forest (C), all in six replicates. Thus in total, 72 traps were used per one sampling occasion. Between 2014 and 2018, one-month sampling sessions were conducted per season, one in spring, one in autumn. This regime corresponds with the highest activity peaks of ground beetles (ELEK et al. 2018). The pitfall trap catches were pooled on the plot level, and only activity densities of $C$. coriaceus and C. scheidleri were considered in this study. 
Individual movement - capture-mark-recapture and radio telemetry - Two different approaches were used for recording individual movement. The capture-mark-recapture (CMR) was applied to $C$. scheidleri, while $C$. coriaceus was radio-tracked. The CMR of $C$. scheidleri was conducted in two blocks during spring 2017. We installed $10(2 \times 5)$ empty pitfall traps in $4 \mathrm{~m}$ grid in CC and P treatments and adjoining control forests. The distance between trap groups in the treatment and corresponding control plot was approximately $40 \mathrm{~m}$. Traps were checked every five or six days, and collected beetles were individually marked by engraved numbers on their elytra and released nearby. We recorded movements within and between habitats.

The individual movement patterns of $C$. coriaceus were studied by radio telemetry in autumn 2018. Six living individuals (three males and three females) were collected in the experimental area by empty pitfall traps. Small VHF transmitters with unique frequencies (the PicoPip model, weight of $0.29 \mathrm{~g}$, Biotrack Ltd, Wareham, England) were mounted on the top of elytra by superglue. Tagged beetles were released in the treatment core (P or $\mathrm{CC})$, on its edge, and in the adjoining control forest. They were tracked every four hours for five consecutive days (for details see ELEK et al. 2019) and their locations were recorded by GPS device (Garmin Dakota 20, in WGS84 coordinate reference system). Based on the positional data, we calculated mean walking speed $(\mathrm{m} / \mathrm{h})$, the proportion of active time (i.e. time when beetles moved), and obtained trajectory profile.

Statistical analyses - We used generalized linear mixed models with the Poisson distribution to test the effects of forestry treatments (both species), mean walking speed and the proportion of active time (only C. coriaceus) on the activity density. In the case of $C$. coriaceus, we created single-argument models on each response variable (the glmer function in 'lme4' package, BATES et al. 2015) where year and block were used as random effects. Afterwards, all models were tested to select the best one based on the Akaike Information Criterion (AICc) corrected for small sample sizes (BuRnHAM \& ANDERson 2002) using the model.sel function in 'MuMIn' package (BARToŃ 2019). When AICc was lower than 2, the model was selected as the most parsimonious explanation for the fitted data. If any significant differences for the explanatory factor-type variable "forestry treatments" were detected, we used post-hoc test with Tukey contrasts for multiple comparisons of means (BRETz et al. 2010) by the glht function in 'multcomp' package (HотноRN et al. 2008). All analyses were conducted in R 3.6.1 (R Core Team 2019).

\section{RESULTS}

Carabus scheidleri - Between 2014 and 2018, we collected 1955 individuals of $C$. scheidleri. Its activity density significantly differed between treatments $\left(\chi^{2}=46.067, \mathrm{df}=2, \mathrm{p}<0.001\right)$, it was higher in both treatments $(C C, P)$ than in $C$ (Fig. 1a). For CMR, we captured and marked 102 individuals of $C$. scheidleri in total; 56 males and 46 females, respectively. We captured 19 beetles in control forest, 60 in CC, and 23 in P. We recorded 10 movements (recaptures), most of them within the particular treatment. In three cases, beetles left the treatment (CC or P) and walked to control forest stands. No movement was recorded in the opposite direction, i.e. from control stands to the treatments (Fig. 2a).

Carabus coriaceus - In total, we collected 723 individuals of $C$. coriaceus. The model selection based on the calculated AICc revealed that the 'treatment' model was the most parsimonious explanation of the activity density 
Table 1. Summary of the model selection for the activity density of $C$. coriaceus, using estimations based on the calculated AICc value of the models, serving as the weight of evidence in favor of the different models. Most parsimonious model (delta $<2$ ) is emphasized in bold.

\begin{tabular}{lccccc}
\hline Models & df & logLik & AICc & Delta & Weight \\
\hline Treatment & $\mathbf{5}$ & $\mathbf{- 3 3 8 . 6 5 4}$ & $\mathbf{6 8 7 . 8}$ & $\mathbf{0 . 0 0}$ & $\mathbf{0 . 7 6 9}$ \\
Mean speed & 4 & -341.240 & 690.8 & 2.99 & 0.173 \\
Active time & 4 & -342.601 & 693.6 & 5.71 & 0.044 \\
null & 3 & -344.845 & 695.9 & 8.05 & 0.014 \\
\hline
\end{tabular}
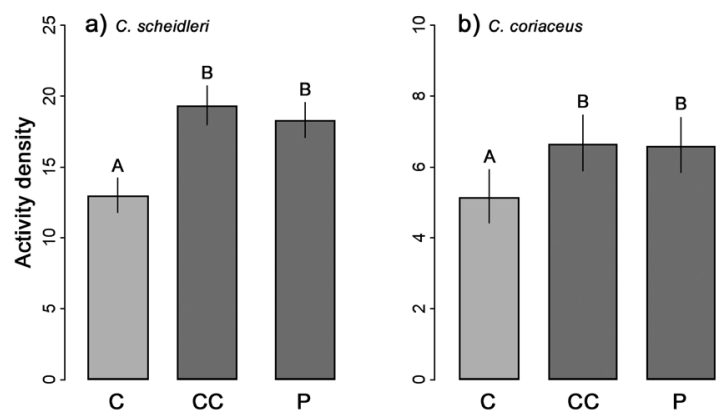

Fig. 1. Mean activity density of Carabus scheidleri (a) and C. coriaceus (b) per sampling plot in different forestry treatments $(\mathrm{C}=$ control, $\mathrm{CC}=$ clear-cutting, $\mathrm{P}=$ preparation cutting) between 2014 and 2018. Vertical lines represent a $95 \%$ confidence interval and capital letters above bars indicate significant differences based on Tukey's multiple comparisons of means

data (Table 1). Similarly to C. scheidleri, the activity density of C. coriaceus was significantly higher in both treatments than in the control forest $\left(\chi^{2}=11.897\right.$, $\mathrm{df}=2, \mathrm{p}=0.002$; Fig. $1 b$ ). In contrast, the individual trajectories showed that beetles used both treatments only temporarily. They were faster and more active in $\mathrm{P}$ and CC than control forest (mean speed: $0.56 \mathrm{~m} / \mathrm{h}$ in $\mathrm{P}, 0.33 \mathrm{~m} / \mathrm{h}$ in CC, and $0.26 \mathrm{~m} / \mathrm{h}$ in C; active time: $38 \%$ in $\mathrm{P}, 21 \%$ in CC and $18 \%$ in C). They also left preparation cutting and clear-cutting within few days (Fig. 2b).

a) c. scheidleri

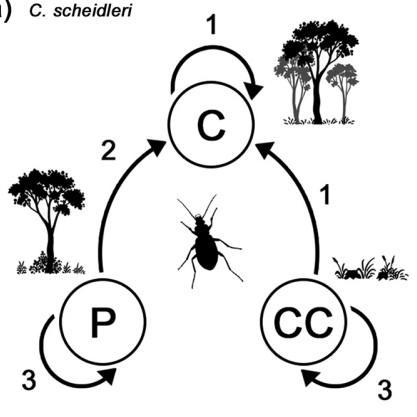

b) C. coriaceus

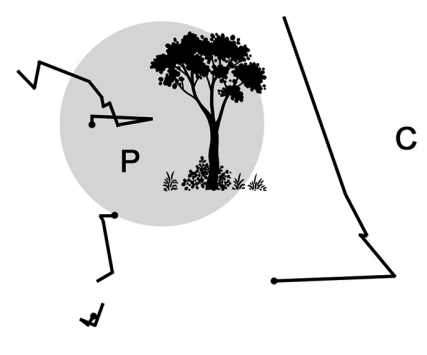

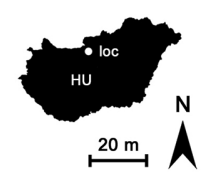

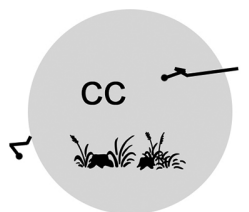

Fig. 2. Movements of Carabus scheidleri (a) within and between forestry treatments $(\mathrm{C}=$ control, $\mathrm{CC}=$ clear-cutting, $\mathrm{P}=$ preparation cutting) based on CMR. The number next to the arrow corresponds with the number of recorded movements. Individual trajectories of radio-tracked $C$. coriaceus (b) in the experimental area, black dots represent the first release point for each trajectory 


\section{DISCUSSION}

Among ecologists, activity density is a widely used and important characteristic for community measures in ground-dwelling arthropods (LöveI \& Sunderland 1996, Thomas et al. 1998). What activity density can tell about a particular species or assemblage is predominantly based on the movement of individuals as well as their population densities. Movement-related behavioural aspects, such as walking speed, the proportion of active time, or tortuosity of trajectory, usually change in response to different (micro)habitat utilization and/or particular part of the season (e.g. BaARs 1979, NieHuEs et al. 1996, BÉRCes \& RŮžIČKová 2019). As we showed here, pitfall traps catch can not be equivalent to positive habitat preference following a well-known rule: higher activity density, higher preference of the sampling site. We found an indirect link between activity density and individual movement of both Carabus species through treatment types. The activity density was significantly higher in both treatments than in control plots which may, at first glance, indicate that $C$. scheidleri, as well as $C$. coriaceus, tended to prefer managed habitats over undisturbed oak-hornbeam forest. Nevertheless, looking closely at individual movements, beetles used preparation cutting and clear-cutting plots only temporally: they were more active there, moved faster, and left the original release site within a few days.

GRÜM $(1971 a, b)$ found that the pitfall catches could be higher in unsuitable habitats since individuals are more active there because they want to avoid adverse environmental conditions. Indeed, the activity density of endemic species of Italian Alps, C. olympiae, was higher in rose shrubbery than in surrounding beech forest stands, but individual trajectories were less tortuous in shrubs (Negro et al. 2008). Although individuals did not leave the original habitat of release (a size of an experimental area was higher with an order of magnitude than ours), the authors assumed that beetles were induced to move more in rose shrubbery than in adjoining forest likely due to higher extremes in temperatures or to avoid predators.

What is the ecological relevance of the fact that the beetles were more active in unsuitable habitats? In undisturbed forests, various Carabus species may compete to limited food resources due to high spatial homogeneity in forest structure while clear-cuttings and preparation cuttings might ameliorate this competition (LENSKI 1982); such phenomenon can be described as an ecological trap (Ewers \& Didham 2005). This is especially true for C. scheidleri, which is associated with newly disturbed, human-modified habitats suggesting its relatively low competitiveness in homogeneous forests (ANDORKó \& KÁDÁr 2006). Moreover for strictly forest species, the artificial edges, as a result of treatment implementation, can act as filters limiting their move- 
ment out of forest stands and leaving treatments unoccupied (MAGURA et al. 2017, 2019, Magura \& Lövei 2020). The majority of normal activity is connected with foraging, and starving beetles are more active than satisfied ones to increase their likelihood of encountering food (GRÜM 1971a, LENSKI 1984). Besides, we can presume that the spatio-temporal distribution of predatory ground beetles may follow potential prey changes due to the alterations in environmental conditions after forest management (KovÁcs et al. 2018, 2020, TINYA et al. 2019). Thus, the high variation in abundance in both treatments might suggest that these habitats act as temporary foraging sites. These findings can be supported by no recorded movement of $C$. scheidleri from control forest stands to any of the treatments.

Moreover, its relatively low recapture rate (approximately 10\%) can be indicative for emigration from the treatments after feeding, especially from clear-cuttings. Similarly, radio-tracked C. coriaceus individuals left both treatments quickly, and trajectories showed a typical carabid movement behaviour when random non-directional walk in short distances alternated with directed movement, i.e. long covered distances in a constant direction. While the random walk is considered as foraging behaviour, directed movement is an efficient strategy for dispersal through the filtering of unsuitable sites, possibly supported by orientation towards a dark forest silhouette (THIELE 1977, BaArs 1979, Niehues et al. 1996, Riecken \& Raths 1996).

However, the species identity, the inner motivation (hunger level), and prey density can also be determining factors for the dominance of one or the other movement state (Wallin \& Еквом 1994). For instance, in high aphid density, Poecilus cupreus (Linnaeus, 1758) displayed directed movements regardless of hunger level, whereas the movement of Pterostichus melanarius (Illiger, 1798) was described mostly as a random walk (WaLLin \& Еквом 1994). Thus, individuals' behavioural peculiarities can notably affect movement activity and, consequently, the numbers of pitfall trap catches.

In conclusion, statements concerning a species composition of carabid assemblages and habitat preferences derived from pitfall traps seem to be heavily biased by the individual plasticity in movement behaviour. Activity density should be carefully considered as a relative measure for ground-dwelling arthropods and, in an ideal case, should be supported by additional methods recording individual movement, such as capture-mark-recapture or radio telemetry. Only then, pitfall catches and activity density can reveal reliable patterns in habitat utilization. Nevertheless, it has to be noted that our results are based on a relatively small-scale study; we, therefore, encourage other researches to explore more in detail the link between activity density and individual movement regarding other carabid species and different habitats. 
Acknowledgements - We thank two anonymous reviewers for improving the manuscript. This research was supported by the Hungarian Research Fund (OTKA 111887) and the National Research, Development and Innovation Fund (grant no. K_18 128441).

\section{REFERENCES}

Andorkó, R. \& KádáR, F. (2006): Carabid beetle (Coleoptera: Carabidae) communities in a woodland habitat in Hungary. - Entomologica Fennica 17: 221-228. https://doi. org/10.33338/ef.84334

Andorkó, R. \& KÁdÁR, F. (2009): Life-history characteristics of the ground beetle Carabus scheidleri (Coleoptera: Carabidae) in Hungary. - Acta Zoologica Academiae Scientiarum Hungaricae 55: 381-393.

BAARs, M. A. (1979): Patterns of movement of radioactive carabid beetles. - Oecologia 44: 125-140. https://doi.org/10.1007/BF00346411

Bailey, J. D., Benefer, C. M., Blackshaw, R. P. \& Codling, E. A. (2020): Walking behaviour in the ground beetle, Poecilus cupreus: dispersal potential, intermittency and individual variation. - Bulletin of Entomological Research 1-10. https://doi.org/10.1017/ S0007485320000565

BARToŃ,K.(2019):MuMIn:Multi-Model Inference.https://CRAN.R-project.org/package=MuMIn

Bates, D., Mächler, M., Bolker, B. \& Walker, S. (2015): Fitting Linear Mixed-Effects Models Using lme4. - Journal of Statistical Software 67: 1-48. http://dx.doi.org/10.18637/jss.v067.i01

BÉrCES, S. \& RŮŽičKovÁ, J. (2019): Habitat use of an endangered beetle Carabus hungaricus assessed via radio telemetry. - Acta Zoologica Academiae Scientiarum Hungaricae 65: 335-348. https://doi.org/10.17109/AZH.65.4.335.2019

Bretz, F., Hothorn, T. \& Westfall, P. (2010): Multiple Comparisons Using R. - CRC Press, Boca Raton, 208 pp.

Brown, G. R. \& Matthews, I. M. (2016): A review of extensive variation in the design of pitfall traps and a proposal for a standard pitfall trap design for monitoring groundactive arthropod biodiversity. - Ecology and Evolution 6: 3953-3964. https://doi. org/10.1002/ece3.2176

Burnham, K. P. \& Anderson, D. R. (2002): Model Selection and Multimodel Inference: A Practical Information Theoretic Approach. - Springer-Verlag, New York, 488 pp.

Elek, Z., Kovács, B., Aszalós, R., Boros, G., Samu, F., Tinya, F. \& Ódor, P. (2018): Taxonspecific responses to different forestry treatments in a temperate forest. - Scientific Reports 8: 16990. https://doi.org/10.1038/s41598-018-35159-z

EleK, Z., RŮžIČKovÁ, J. \& ÓDor, P. (2019): Individual decisions drive the changes in movement patterns of ground beetles between forestry management types in Hungary. Pp. 79. In: 2nd International Conference on Community Ecology, Book of abstracts. - Akadémiai Kiadó, Budapest.

Ewers, R. M. \& Didham, R. K. (2005): Confounding factors in the detection of species responses to habitat fragmentation. - Biological Reviews 81: 117-142. https://doi. org/10.1017/s1464793105006949

Greenslade, P. J. M. (1964): Pitfall trapping as a method for studying populations of Carabidae (Coleoptera). - The Journal of Animal Ecology 33: 301-310. https://doi. org/10.2307/2632 
GrüM, L. (1971a): Spatial differentiation of the Carabus L. (Carabidae, Coleoptera) mobility. - Ekologia Polska Ser. A 19: 1-34.

GRÜM, L. (1971b): Remarks on the differentiation in Carabidae mobility. - Ekologia Polska Ser. A 19: 47-56.

Halsall, N. B. \& Wratten, S. D. (1988): The efficiency of pitfall trapping for polyphagous predatory Carabidae. - Ecological Entomology 13: 293-299. https://doi. org/10.1111/j.1365-2311.1988.tb00359.x

HonĚK, A. (1997): The effect of temperature on the activity of Carabidae (Coleoptera) in a fallow field. - European Journal of Entomology 94: 97-104.

Hothorn, T., Bretz, F. \& Westfall, P. (2008): Simultaneous inference in general parametric models. - Biometrical Journal 50: 346-363. https://doi.org/10.1002/bimj.200810425

KÁDÁr, F., ANDorkó, R. \& EleK, Z. (2017): Reproductive characteristics and habitat selection of Carabus ulrichii (Coleoptera, Carabidae) in woodland habitats in Hungary. - Acta Zoologica Academiae Scientiarum Hungaricae 63: 343-354. https://doi.org//10.17109/ AZH.63.3.343.2017

Kagawa, Y. \& Maeto, K. (2009): Spatial population structure of the predatory ground beetle Carabus yaconinus (Coleoptera: Carabidae) in the mixed farmland-woodland satoyama landscape of Japan. - European Journal of Entomology 106: 385-391. https://doi. org//10.14411/eje.2009.049

Kotze, D. J., Brandmayr, P., Casale, A., Dauffy-Richard, E., Dekoninck, W., Koivula, M. J., Lövei, G. L., Mossakowski, D., Noordijk, J., Paarmann, W., Pizzolotto, R., Saska, P., Schwerk, A., Serrano, J., Szyszko, J., Taboada, A., Turin, H., Venn, S., VermeuLEN, R. \& Zетto, T. (2011): Forty years of carabid beetle research in Europe-from taxonomy, biology, ecology and population studies to bioindication, habitat assessment and conservation. - ZooKeys 100: 55-148. https://doi.org/10.3897/zookeys.100.1523

Kovács, B., Tinya, F., Guba, E., Németh, Cs., Sass, V., Bidló, A. \& Ódor, P. (2018): The short-term effects of experimental forestry treatments on site conditions in an oakhornbeam forest. - Forests 9: 406. https://doi.org/10.3390/f9070406

Kovács, B., Tinya, F., Németh, Cs. \& Ódor, P. (2020): Unfolding the effects of different forestry treatments on microclimate in oak forests: results of a 4-yr experiment. - Ecological Applications 30: e02043. https://doi.org/10.1002/eap.2043

LANG, A. (2000): The pitfalls of pitfalls: a comparison of pitfall trap catches and absolute density estimates of epigeal invertebrate predators in arable land. - Journal of Pest Science 73: 99-106. https://doi.org/10.1007/BF02956438

LENSKI, R. E. (1982): Effects of forest cutting on two Carabus species: evidence for competition for food. - Ecology 63: 1211-1217. https://doi.org/10.2307/1938845

LENSKI, R. E. (1984): Food limitation and competition: a field experiment with two Carabus species. - The Journal of Animal Ecology 53: 203-216. https://doi.org/10.2307/4352

Lövei, G. L. \& SunderLANd, K. D. (1996): Ecology and behavior of ground beetles (Coleoptera: Carabidae). - Annual Review of Entomology 41: 231-256. https://doi.org/10.1146/ annurev.en.41.010196.001311

Magura, T. \& LöveI, G. L. (2020): The permeability of natural versus anthropogenic forest edges modulates the abundance of ground beetles of different dispersal power and habitat affinity. - Diversity 12: 320. https://doi.org/10.3390/d12090320

Magura, T., Lövei, G. L. \& Tóthmérész, B. (2017): Edge responses are different in edges under natural versus anthropogenic influence: a meta-analysis using ground beetles. - Ecology and Evolution 7: 1009-1017. https://doi.org/10.1002/ece3.2722

Magura, T., Lövei, G. L. \& Tóthmérész, B. (2019): Various edge response of ground beetles in edges under natural versus anthropogenic influence: A meta-analysis using 
life-history traits. - Acta Zoologica Academiae Scientiarum Hungaricae 65(Suppl.): 3-20. https://doi.org/10.17109/AZH.65.Suppl.3.2019

Negro, M., Casale, A., Migliore, L., Palestrini, C. \& Rolando, A. (2008): Habitat use and movement patterns in the endangered ground beetle species, Carabus olympiae (Coleoptera: Carabidae). - European Journal of Entomology 105: 105-112. https://doi. org/10.14411/eje.2008.015

Niehues, F. J., Hockmann, P. \& Weber, F. (1996): Genetics and dynamics of a Carabus auronitens metapopulation in the Westphalian Lowlands (Coleoptera, Carabidae). Annales Zoologici Fennici 33: 85-96.

R Core TeAm (2019): R: A language and environment for statistical computing. - R Foundation for Statistical Computing, Vienna. https://www.R-project.org

Riecken, U. \& RAths, U. (1996): Use of radio telemetry for studying dispersal and habitat use of Carabus coriaceus L. - Annales Zoologici Fennici 33: 109-116.

RŮŽičKová, J. \& VeselÝ, M. (2016): Using radio telemetry to track ground beetles: Movement of Carabus ullrichii. - Biologia 71: 924-930. https://doi.org/10.1515/biolog-2016-0108

Saska, P., van der Werf, W., Hemerik, L., Luff, M. L., Hatten, T. D. \& HoněK, A. (2013): Temperature effects on pitfall catches of epigeal arthropods: a model and method for bias correction. - Journal of Applied Ecology 50: 181-189. https://doi.org/10.1111/13652664.12023

Szyszko, J., Gryuntal, S. \& Schwerk, A. (2004): Differences in locomotory activity between male and female Carabus hortensis (Coleoptera: Carabidae) in a pine forest and a beech forest in relation to feeding state. - Environmental Entomology 33: 1442-1446. https://doi.org/10.1603/0046-225X-33.5.1442

Szyszko, J., Gryuntal, S. \& Schwerk, A. (2005): Nocturnal activity of Carabus hortensis L. (Coleoptera, Carabidae) in two forest sites studied with harmonic radar method. Polish Journal of Ecology 53: 117-121.

Thiele, H. U. (1977): Carabid beetles in their environments. - Springer, Berlin, 369 pp. https:// doi.org/10.1007/978-3-642-81154-8

Thomas, C. F. G., Parkinson, L. \& Marshall, E. J. P. (1998): Isolating the components of activity-density for the carabid beetle Pterostichus melanarius in farmland. - Oecologia 116: 103-112. https://doi.org/10.1007/s004420050568

Tinya, F., Kovács, B., Prättälä, A., Farkas, P., Aszalós, R. \& Ódor, P. (2019): Initial understory response to experimental silvicultural treatments in a temperate oak-dominated forest. - European Journal of Forest Research 138: 65-77. https://doi.org/10.1007/ s10342-018-1154-8

Topping, C. J. \& Sunderland, K. D. (1992): Limitations to the use of pitfall traps in ecological studies exemplified by a study of spiders in a field of winter wheat. - Journal of Applied Ecology 29: 485-491. https://doi.org/10.2307/2404516

Turin, H., Penev, L. \& Casale, A. (2003): The genus Carabus in Europe. A synthesis. - Pensoft, Sofia-Moscow-Leiden, 511 pp.

Wallin, H. \& Еквом, B. (1994): Influence of hunger level and prey densities on movement patterns in three species of Pterostichus beetles (Coleoptera: Carabidae). - Environmental Entomology 23: 1171-1181. https://doi.org/10.1093/ee/23.5.1171

Woodсоск, B. A. (2005): Pitfall trapping in ecological studies. Pp. 37-57. In: LeAthER, S. R. (ed.): Insect sampling in forest ecosystems. - Wiley-Blackwell. https://doi. org/10.1002/9780470750513.ch3

Received October 27, 2020, accepted December 29, 2020, published February 22, 2021 